\title{
Reductions of the Internal and External Samians in Greece: A Contribution to the Study of the Cultural Dimension Tourism
}

\author{
MG Varvounis* and N Rodosthenous \\ Professor of Folklore, Department of History and Ethnology, Democritus University of Thrace, Greece
}

*Corresponding author: MG Varvounis, Professor of Folklore, Department of History and Ethnology, Democritus University of Thrace, Greece.

Received Date: November 26, 2019

Published Date: December 03, 2019

Abstract

In this study, the strictly satirical cans the Samians (the inhabitants of the Greek island of Samos) have created and used for their emigrant compatriots (living in Greece and not) will be examined. These canons are examined as to their substance and use, and as to the cultural dimensions of tourism in Samos. Certain conclusions are extracted by the study, such as the way the residents of Samos face their emigrant's compatriots, and all the elements of their daily life, which are different from their elements.

\section{Introduction}

However, the political difference with the native Samians, the inhabitants of the Greek island of Samos, is obvious, as well as both internal and external migrants, live in different cultural environments, a fact that contributes to the differentiation they all have. This reality is apprehended by the Samians, who later express it through multiple strict satirical characterizations, where the latter is later examined, as fine examples of a cultural and social dimension of the touristic phenomenon the same way it exists in the Greek island of Samos.

\section{Historical dimensions}

As early as the interwar period, Samians (i.e. inhabitants of the island of Samos, in Greece) expatriates of the interior visited their birthplace, especially during the summer months. A habit found primarily in the two urban centres of the island, Limin VA Theos (i.e. port of Vathi, the capital of the island) and Karlovassi (the second town of the island of Samos) which was maximized after the Second World War, with the massive internal and external migration of the inhabitants of Samos. The first internal and external migrants who had left their ancestral homes in the late 19th century, primarily due to the destruction of the vines by phyllo era but also, immediately after the union of Samos with Greece in 1912, they found successors to the emigrants as a result of the occupation and the bloody Samian
Civil War. In search of their birthplace, the expatriates tried to visit their homeland during holidays.

For the inhabitants of Samos, the seasonal appearance on the island of those who had moved was a real challenge, something which continues till today. As relatives and friends had been separated, their departure from the island's society had created a psychological and cultural division which was practically and symbolically unbridgeable [1-3] Some aspects of these situations, which partly continue to today, will be considered and then considered complementary to the above, were written about the satirical hierarchies of foreign visitors to Samos [4,5].

The "Athenians", the "Americans" and the immigration trauma

Soon, the place of residence and origin of the emigrants became their most well-known and widespread hetero determination [6]. Primarily the "Athenians", as, behind this collective definition, the Samians classify almost all the internal immigrants of their island, even if they do not live in the Attica basin. So those who reside elsewhere such as Thessaloniki and other Greek provincial cities are often referred to as "Athenians". This may be due to the fact that, firstly most of the Samian expatriates actually migrated to areas of the basin-collectively called "Athens" and secondly, the capital 
held a hegemonic and sovereign position in their thinking, so that all internal immigrants are connected with it. Besides, the flow of tourism, and more so in the case of the expatriate visitors, is part of the plan for the "modernization" of the Samian society, as it is expressed by the rhetoric of local hegemonic social and economic classes [7] but also on the basis of the "cultural exploitation" of many forms of the Samian traditional culture [8], as the bibliography has shown.

On the other hand, before the Second World War, the Sami people were mainly immigrants to America, the United States. The "Americans", also referred to as "America" by the inhabitants of the island- so that the external immigrants of Samos can qualify as "Americans". In the second half of the 20th century, when migration began to other parts of the world, close to them Australians" and "Canadians" were added. The Samian immigrants in Western Europe are just "foreigners" and are not included in the "American" category, even if they live in European regions [9]. A concealed rivalry has developed among the permanent residents of the island and its seasonal expatriate visitors, which basically has cultural roots. The trauma of immigration and settlement in foreign places, as well as the need to adapt to survive, have contributed so that emigrants gradually adopted attitudes and behaviours largely foreign to the inhabitants of the island. At this point it should be noted that although similar developments are taking place in many regions of Greece [10] folklore has not yet dealt with this interesting issue therefore this short study to be characterized as a first and cumbersome approach to the issue, which should be extended in the future, so that relations between permanent residents and seasonal visitors be researched by their folkloric dimension.

As Adrian Furnham [11,12] observes, here we have aspects of the appearance of cultural shock that tourism often causes to residents of destination sites, particularly those who are not involved in the flow of tourist professions and associated fields. In this case, this is not easy to understand, as it is an element of contact between locals, friends, acquaintances or relatives, who partly share the same cultural situations, but also the sense of "coownership" which governs every local community. It should be noted that, as can be seen from similar cultural developments in other tourist areas $[13,14]$, the content of the sense of this common affiliation is differentiated according to the circumstances of each place. In this case, it is not only the common origin and the same national, religious and cultural identity, but also the special sense created by the Samian origin, the "self-esteem", which builds the sense of joint affiliation and serves as a connecting means for these people.

The inhabitants of Samos $[15,16]$ attribute to the "Athenians" strange behaviour outside the daily social practice and the prevailing values in the traditional society of Samos in the past but also in the present day. They also account for them a tendency to demonstrate, through which they try to justify their removal from their birthplace and simultaneously symbolically show their superiority over their local compatriots. In this respect, the comprehensive characterization "Athenaeums" is not a simple nickname, integrated into the relative tradition of the island, but a whole cultural category, which includes all the emigrants of Samos who live in Greece. This cultural category includes mainly stereotypes, stereotypes related to the form of the tourist, from what Jeffrey D. Brewer studied [17-19], like that of an annoying relative who comes for his summer vacation and burdens his friends and acquaintances with the nuisance of the traditional content of hospitality provision of shelter, treats, invitations to eat at home or outside, etc. "Mussafirides" (i.e. foreign for hospitality) often appear in the discussions of Sami as the permanent summer nightmare, which is consternation, inconvenience, fatigue and discomfort the inhabitants of the island. It also includes stereotyped narratives about the strange, often liberating, manners of the "Athenians" for their sophisticated attire, especially during the Sunday ecclesiastics and the summer festivals, with which they seek to emphasize the supposed superiority they consider distinguishing them, against the locals.

Even variations of faded narratives about the supremacy of the intelligent and uneducated village against the butt, but educated bourgeois fit into this figure, with the locals holding the first place, and visitors the second. As can be seen in the relevant literature, [20-23] these stories often act as ways of gathering the locals, and as symbolic narrative boundaries between "we" and "the others". In fact, Kalissa Alexeyeff [24] observes that in these stories is often the erotic character and the references to the ethics of the visitors of a place, in this case the expatriate Sami, especially the children and their descendants in general, which is seen as a further differentiating factor in relation to the local community.

\section{Cultural stereotypes}

On the other hand, the "Americans"- this characterization will then be used collectively for the foreign emigrants of Samos, despite the distinctions noted above-follow the same course, with more distinct boundaries. Living abroad they have adopted many language elements of a foreign language rule from English, which contributes to both discrimination as well as in their satirists [25-27]. Their choice of dress and eating habits are also often a subject of satirical commentary, since they differ from those of the natives. In fact, the further we go back we can see these differences were more blatant and more impressive. The locals attribute to the "Americans" the tendency to show off, noting that they are suffocating in their new homelands, and working there without rest, to raise money to live richly for 'only a month' in the summer.

Frequently in the narrative is the notion that they try, without believing, to prove how high quality their lives are overseas, while in fact they live worse than the inhabitants of the island.

So, they think that the "Americans" in their narratives are lying, in order to impart to them and their family's prestige, but also to justify their choices. As a proof of this claim, the locals report that many of the Americans just retired to repatriate to live their last years in the village and on their island, which they would not have done if they were living comfortably and pleasantly. During the summer holidays "Athenians" and "Americans" are constantly under 
the state of the social control mechanisms, which exist and operate in the traditional society of the island. Both private life and, above all, their public presence in the café, the church and the fairs are the subject of individual and collective annotations by the locals. Thus, their initial treatment as desirable visitors, who even temporarily re-give life to the declining villages of Samos, is partly invalidated by criticism, which is based on the fact that they often behave and operate within the community differently than is expected or even socially permissible $[28,29]$.

We should not forget here, the economic dimension of this kind of tourism of the expatriates in the context of the general economic functionality of the tourist stream, which is closely linked to the introduction of new customs and habits of traditional everyday life, as the relevant literature points out [30-32]. In this regard, a significant part of the acceptance of the "Athenians" and "Americans" is based on the recognition of their financial contribution to the Samian life, which minimizes the responses to lifestyles and ideas that often follow and which its community each village tends to be annoying or native. Even at the level of children, these characterizations and perceptions are projected and reproduced. For the children of the villages of Samos, the children of their emigrant compatriots are also the "Athenians", who gradually integrate in their groups. It should be stressed that while daily relation between expatriates and locals are characterized by mutual acceptance and development of multilevel contacts, in cases of critical issues or crises related to collective decisions and actions, differentiations emerge and dominate.

The concept, for example, that the "Athenians" want to determine the life and habits of a place in which they do not live, and which they essentially abandoned, dominates this rhetoric [3335], the rhetoric of a closed social formation, tending to symbolic marginalization, and to once again join a place with borders and boundaries. According to these perceptions, the "Athenians" are involved in some external decisions and acts of the community, but they participate in the core of social formation and hence in the making of substantive decisions. This, in turn, determines both the position that they themselves seek to occupy in the Samian society and the role that is recognized by them [36]. Both parameters, of course, have cultural implications, and influence both the behaviour and the social integration of the expatriate, national and foreign, with different manifestations of course in these two distinct categories. In the position of both the "Athenians" and the "Americans" they do not always perceive the same terms their seasonal presence on the native island has and their coexistence with the locals, dedicated to the emotional service of their nostalgia, which in turn is a characteristic manifestation of the trauma of separation from their island. Those who experience their villages each year are recruited by themselves as a recurring process of reintegration into a social fabric from which they have been abducted, suddenly and violently. That is why their behaviour is more ritualistic, and less socially flamboyant, something that the locals do not understand as they engage their relationship with the island and its people from a totally different perspective.
According to this process, the separation of the foreigner follows the initiatory participation in the social, recreational and religious events of the community in order to achieve their ritual integration into the society of the village and their island. This is a figure that Erd. Gormsen [37,38], who associates it with the nostalgic foundations that construct the myth of returning to one's birthplace, with all its compassionate psychological effects. It is an essentially imaginative recruitment, with an obvious communicative character, but it is mainly a recurring ritual on an annual basis, which is related to the character of pilgrimage that expatriates often acquire in the birthplace. Only, here we do not have an excursion but a holiday, which is, a more permanent, longer lasting, and seasonal stay.

\section{Living between places and cultures}

Most of the attitudes and behaviours mentioned above stem from the fact that the "Athenians" and "Americans" are treated by the locals as a border situation between native Samian and the tourist $[39,40]$ two categories that dominate the ideological formation and customary practice of the Samian society [41-43]. Thus, the satirical treatment of tourists with their criticism stemming from the inadequate fulfilment of the expectations that every local community has for its members, a phenomenon more widely known and established, as KB Ghimire has shown extensively [44,45], in his study of the "native-tourist" and the cultural and social events related to his presence and action. These are the perceptions of the authenticity of the "acquisition" of popular culture and the concept of locality. Permanent inhabitants of Samos believe, and show it at every opportunity, that they are "Genuine" Samians, the original expressers of the spirit and players of the island's culture. Iirt should be noted here that similar discussions and differentiations are common in areas that are either distinguished by the tourist stream they attract or have a large number of expatriates who maintain relations with the birthplace, as Michael F. Brown [46] has shown, studying a series relevant examples from different regions.

This is supported primarily by the fact that the "Athenians", and more so, the "Americans" do not live on the island, do not experience the problems of their everyday life but use it as a place of relaxation and holiday. Therefore, they consider that they cannot have a primary say in the issues of Samoa, since they do not concern them directly, but also because they left Samos to look elsewhere for livelihood, or even ways of better life [47-49]. On the other hand expatriates stress both emotional bonds that tie them to their place of origin, and their economic contribution to its development, by the seasonal even their living, but also through donations, projects and actions that support either at an individual level or through their associations [50-52]. This dichotomous perception leads to a subdivided often differentiation, which contributes to the encroachment of the expatriates within the boundaries of their associations, for which we have also spoken on another occasion, and to the pooling of their actions in these unions. It is quite characteristic that during the summer holiday season, especially July and August, the scope of action of these unions is transferred to Samos, where most of their members and their board members 
spend the summer. Besides, during this period it is almost a daily occurrence of the cultural, recreational and social events of the unions, as has been noted by C.A. Toledo [53] in all the villages of the island, which an indicative case for the above. And it is this phenomenon that largely determines the cultural life of Samos, at least in the summer months.

In this context, the ritual reconnection with the birthplace, which for the "Athenians" and "Americans" takes the significance of a sacred duty towards the homeland, is interpreted by the locals within the framework of their everyday life. A debt associated with the "return" pattern to the cultural cradle, an issue which is generally involved in tourism and the cultural impact of aspects, as has been shown in the relevant literature [54], and which is usually not readily understood by the permanent residents of a tourist destination. It is interpreted in the light of a specific view, which often responds to island societies, favoured by geomorphology of island space, which is associated with self-sufficiency [55]. This is a critical treatment, which clearly separates the local from the urgency, which places, as mentioned above, the "Athenians" and "Americans" in a border zone of social functionality and existence [56-59] between local and foreign tourists. In a zone where aspirational and locality are coexisting as distinctive features, with the essential differentiation of the standard of living followed. And so, he acquires a critical tone, the result of which are both all sorts of satirical and sarcastic narratives, as well as the hetero determinations of the Samian expatriates, for which there was a long talk before.

\section{Conclusion}

From previous studies it comes of that the satirical and social characterizations from Greece and abroad, whom which visit Samos during summertime, are particularly important for the understanding of the cultural dimension of tourism in the Samian society. These characterizations are also important for the research of the way of which the tourist wave of migrant Samians work for the residents of this island and for the formation and stabilization of the broader relations they have with their migrant compatriots.

This way, these characterizations of internal and external migrant Samians, which are given by the native Samians during summer vacation, make up the resemblance of the social standing of the migrant Samians, and the cultural components and indications of the tourist wave to the island. And in that context, they are examined as to the studies that came before, since they offer useful conclusions for the cultural functionality of tourism in Samos, and to the social reforms to which they are led, always in accordance to the migrants of the island.

\section{Acknowledgement}

None.

\section{Conflict of Interest}

Author has no conflict of interest.

\section{References}

1. Dimitrios Buhalis, Dimitrios Diamantis (2001) Tourism development and sustainability in the Greek archipelagos in Tourism in the Mediterranean. Routledge, pp. 145-147.

2. Dorothea Schell (2000) Coping with foreigners in a Greek village. Ethnologia Balkanica 4: 117-129.

3. Malcolm Crick (1989) Representations of international tourism in the social sciences: sun, sex, sights, savings, and servility. Annual Review of Anthropology, pp. 307-344.

4. Vasiliki Moutafis (1990) Tourism on Samos: implications for marriage, dowry and women's status. Dissertation Abstracts International. A. Humanities and Social Sciences 51(3): 910-911.

5. Vasiliki Moutafis (1994) From Agriculture to Tourism: Property, Labour, Gender, and Kinship in a Greek Island Village (part II). Journal of Modern Greek Studies 12(1):113-131.

6. Kathy Feng, Stephen J (2000) An exploratory study of the tourism, migration-immigration nexus: Travel experiences of Chinese residents in New Zealand. Current Issues in Tourism 3(3): 246-281.

7. C f Christopher Endy (2004) Cold war holidays: American tourism in France. University of North Carolina Press, pp. 56- 58.

8. Konstantinos Andriotis (2004) The perceived impact of tourism development by Cretan residents. Tourism and Hospitality Planning \& Development 1(2): 123-144.

9. Per. Gustafson (2002) Tourism and seasonal retirement migration. Annals of Tourism Research 29(4): 899-918.

10. Eleftheria Deltsou (2000) Tourists Russian-Pontics and Native Greeks: Identity Politics in a Village in Northern Greece. Anthropological Journal on European Cultures 9(2): 31-51.

11. Adrian Furnham (1984) Tourism and culture shock. Annals of Tourism Research 11(1): 41-57.

12. Cf. Jan Rath (2007) Tourism, ethnic diversity and the city. Routledge, pp. 12-15.

13. Christopher B. Balme (1998) Staging the Pacific: Framing authenticity in performances for tourists at the Polynesian Cultural Centre. Theatre Journal 50(1): 53-70.

14. Habib Saidi (2006) Vadrouilleurs, dervishes and tourists: Going between front stage and backstage in Tunisia. The Journal of North African Studies 11(4): 409-420.

15. Cf. Julie Reeves (2007) Culture and International Relations: Narratives, natives and tourists. Routledge, pp. 34-35.

16. Polly Pattullo (1996) Last resorts: The cost of tourism in the Caribbean, Ian Randle Publishers, pp. 17-19.

17. Jeffrey D. Brewer (1984) Tourism and ethnic stereotypes: Variations in a Mexican town. Annals of Tourism Research 11(3): 487-501.

18. Cf. Asuncion Beerli, Josefa D Martin (2004) Tourists' characteristics and the perceived image of tourist destinations: a quantitative analysis a case study of Lanzarote, Spain. Tourism Management 25(5): 623-636.

19. J E Brougham, Richard W Butler (1981) A segmentation analysis of resident attitudes to the social impact of tourism», Annals of Tourism Research 8(4): 569-590.

20. Maribeth Erb (2000) Understanding tourists: interpretations from Indonesia. Annals of Tourism Research 27(3): 709-736.

21. Liisi Laineste (2005) Targets in Estonian Ethnic Jokes Within the Theory of Ethnic Humour (Ch. Davies). Folklore: Electronic Journal of Folklore 29: 7-24.

22. Kalissa Alexeyeff (2008) Are You Being Served? Sex, Humour and Globalisation in the Cook Islands. Anthropological Forum 18(3): 35-78.

23. Assa Doron (2005) Encountering the other: Pilgrims, tourists and boatmen in the city of Varanasi. The Australian Journal of Anthropology 16(2): 157-178. 
24. Kalissa Alexeyeff, Are You Being Served? op. cit, pp. 45.

25. Erik Cohen (2010) Confirmation versus contestation of tourism theories in tourist jokes. Tourism Analysis 15(1): 3-16.

26. Ron Jenkins, I Nyoman Kiter (1997) Taming the Tourists: Balinese Temple Clowns Preserve Their Village Traditions. Performance Research: On Tourism 2(2): 22-26

27. Fredrick Chiwanga (2014) Understanding the language of tourism: Tanzanian perspective. International Journal of Applied Linguistics 24(2): 147-200.

28. Yiorgos Apostolopoulos, Sevil F Sönmez (1999) From farmers and shepherds to shopkeepers and hoteliers: constituency-differentiated experiences of endogenous tourism in the Greek Island of Zakynthos. International Journal of Tourism Research 1(6): 413-427.

29. George Anastassopoulos, Fragkiskos Filipinos, Paul Phillips (2009) An eclectic investigation of tourism multinationals: Evidence from Greece. International Journal of Hospitality Management 28(2): 185-194.

30. Athanasios P Papadopoulos, Gregory T Papanek's (2005) The determinants of vine grower's employment and policy implications: the case of a Greek island. Agricultural Economics 32(1): 61-72.

31. George Galanos (2013) The Greek Tourism Industry and the Challenge of the Economic Crisis. in Greece's Horizons, Springer Berlin Heidelberg, pp. 131-145.

32. Anna Souchuk (2013) Alles Ist $^{\text {st }}$ Unter der Oberfläche Noch Lebendig: Penetrating the Schöner Schein through Satire in Josef Haslinger's Opernball and Robert Menasse's Schubumkehr. Journal of Austrian Studies 46(1): 71-92.

33. Angela Dikou, Andreas Troumbis (2006) Dive Tourism in North Aegean, Greece: Potential and Prospects. Tourism in Marine Environments 3(2): 131-143.

34. Konstantinos Andriotis (2003) Tourism in Crete: A form of modernization. Current Issues in Tourism 6(1): 23-53.

35. Mike Crang (2006) Circulation and emplacement: the hollowed-out performance of tourism. Travels in Paradox, pp. 47-64.

36. Kyle M Woosnam (2011) Comparing Residents' and Tourists' Emotional Solidarity with One Another. An Extension of Durkheim's Model. Journal of Travel Research 50(6): 615-626.

37. Erdmann Gormsen (1997) The impact of tourism on coastal areas. Geo Journal 42(1): 39-54.

38. Kyle M Woosnam, William C Norman (2010) Measuring residents emotional solidarity with tourists: Scale development of Durkheim's theoretical constructs. Journal of Travel Research 49(3): 365-380.

39. Joan D. Laxson (1991) How we see them: tourism and Native Americans. Annals of Tourism Research 18(3): 365-391.

40. Deirdre Evans, Pritchard (1989) How they see us: Native American images of tourists. Annals of Tourism Research 16(1): 89-105.

41. Nicholas Haralambopoulos, Abraham Pizam (1996) Perceived impacts of tourism: The case of Samos. Annals of Tourism Research 23(3): 503526.
42. David Jamison (1999) Tourism and ethnicity: The brotherhood of coconuts. Annals of Tourism Research 26(4): 944-967.

43. Alex Tickell (2001) Footprints on The Beach: traces of colonial adventure in narratives of independent tourism. Postcolonial Studies 4(1): 39-54.

44. Krishna B Ghimire (2013) The native tourist: Mass tourism within developing countries. Routledge, pp. 248.

45. Yvette Reisinger, Lindsay Turner (1997) Cross-cultural differences in tourism: Indonesian tourists in Australia. Tourism Management 18(3): 139-147.

46. Michael F Brown (2009) Who owns native culture? Harvard University Press, pp. 336.

47. Cf Nick Kontogeorgopoulos (2003) Keeping up with the Joneses Tourists, Travellers, and the Quest for Cultural Authenticity in Southern Thailand. Tourist Studies 3(2): 171-203.

48. Naomi Rosh White, Peter B White (2009) The comfort of strangers: Tourists in the Australian outback. International Journal of Tourism Research 11(2): 143-153.

49. Androniki Kavoura (2007) Advertising of national identity and tourism bureaucracy. Current Issues in Tourism 10(5): 397-414.

50. George Donato's, Possidon Zairis (1991) Seasonality of foreign tourism in the Greek island of Crete. Annals of Tourism Research 18(3): 515-519.

51. Theano S. Terkenli, Marcia L Bellas, Laura Dudley Jenkins (2007) Tourism impacts on local life: Socio-cultural continuity and change in Crete. Aegean Geographical Journal 16: 37-52.

52. Branislav Djurdjev (2011) Interactions between Tourists and Residents: Influence on Tourism Development. Polish Sociological Review 1(173): 107-118.

53. Rodrigo de Azeredo Grünewald (2002) Tourism and cultural revival. Annals of Tourism Research 29(4): 1004-1021.

54. Cheri A Toledo (2007) Digital culture: Immigrants and tourists responding to the natives' drumbeat. International Journal of Teaching and Learning in Higher Education 19(1): 84-92.

55. Guy Assaker, Vincenzo Esposito Vinzi, Peter OConnor (2011) Examining the effect of novelty seeking, satisfaction, and destination image on tourists return pattern: A two factor, non-linear latent growth model. Tourism Management 32(4): 890-901.

56. Dallen Timothy (2002) Tourism and the growth of urban ethnic islands. in Tourism and Migration, Springer Netherlands, pp. 135-151.

57. Hazel Tucker (2001) Tourists and troglodytes: negotiating for sustainability. Annals of Tourism Research 28(4): 868-891.

58. Torben Christensen (1992) Greenland wants tourism. Polar Record 28(164): 62-63.

59. Graham Dann, Erik Cohen (1991) Sociology and tourism. Annals of Tourism Research 18(1): 155-169. 